\title{
Erling Sandmo \\ Chapter 10 \\ Synchronizing the Holy Land: Sacred and Secular Cartography after the Reformation
}

After the Renaissance rediscovery or reinvention of Ptolemaic geography, cartography was defined by its task of projecting the round globe on a flat plane. Its main objective was to provide exact information about the locations, distances, and proportions of the physical world. This was a radical break from the medieval mappae mundi, maps that showed simultaneously a physical, temporal, and spiritual world, centered on Jerusalem. With the new geography and cartography, the world lost its centre - and Jerusalem lost its importance as the axis of the world map - or so it may seem. This chapter discusses the complex exchanges between sacred and secular geography in the early modern period and argues that with the rise of an apparently purely spatial cartography, maps of the Holy Land remain connected to sacred geography and consequently to the Jerusalem code in discrete, but important ways.

\section{The Centre of the Spiritual World}

The most famous of all medieval world maps, the Hereford mappa mundi, still hangs in Hereford Cathedral. It has been there almost continually since it was made around 1300, roughly at the time when Dante wrote his Divine Comedy. Today, it is on public display - behind glass, of course, facing the present with its back to the wall. This means that one of its most poignant details is hidden from sight: the hole from the compass that was used to draw the perfect circle of the world. ${ }^{1}$ The hole is not only the centre of the world; it is also the centre of Jerusalem - the two are one.

The map contains a wealth of information on what can be seen as different levels. One such level could obviously be classified as geography: the Mediterranean Sea is a focal point, reaching downwards, and westwards towards the strait of

1 3D scan images, including images of this perforation, can be seen at Mappa Mundi "Mappa Mundi Exploration,” accessed 09.09.19, https://www.themappamundi.co.uk/mappa-mundi.

Note: Thank you to Djoeke van Netten, University of Amsterdam, for her valuable comments to an earlier version of this text.

Erling Sandmo, (1963-2020), Professor of History, University of Oslo; Director, The Map Centre, The National Library of Norway

Ә Open Access. (C) 2021 Erling Sandmo, published by De Gruyter. (c) BY-NC-ND This work is licensed under the Creative Commons Attribution-NonCommercial-NoDerivatives 4.0 International License.

https://doi.org/10.1515/9783110639452-011 
Gibraltar. Europe covers the lower left quarter of the map, Africa the lower right; the upper half is Asia - although most of the continent is taken up by the Holy Land. This area is filled with images from another level of information - biblical history from Noah's Ark on Ararat to the crucifixion. The Red Sea is red, divided dramatically by the long, twisted line delineating the Israelites' journey from Egypt. Other levels are ethnography, natural history, and, finally, images of the temporal conditions of the map and its world: the Day of Judgement, Emperor Augustus sending forth his scribes - drawing a parallel between census and mapping, both as a means of control and discipline - and, possibly, the reader of the map setting out to explore the world and transform it into an object of both knowledge and thought. ${ }^{2}$

The abundance of texts and images is overwhelming, but arguably the most complex questions of all are contained in the minute hole left by the compass. They are questions about the historical ontology and epistemology of maps, and consequently of the world. Our contemporary maps are typically realistic images of the world, as a whole or as parts - the world understood, then, as a physical phenomenon which can be projected onto a flat sheet, an image created by means of certain techniques and with varying degrees of precision. These maps are representations of physical space, they are a media for knowledge of geography, albeit in a broad sense. They are also typically portable, and at least in principle are possible to take to the spaces they represent - but the maps that have happened to survive to our own times have usually not been made for that purpose. Those that were, are mostly lost.

Analytical concepts such as physicality, spatiality, projection, geography, mediality, and portability are difficult to apply across the centuries. The Hereford mappa mundi is not least a map of time and of times: sacred, worldly, eternal, historical. Its juxtapositions of elements from different realms of knowledge remind us of Michel Foucault's famous essay "Of Different Spaces": this world is a heterotopia, a space which contains different spaces, so to speak, like cemeteries, ships, and hotels.

We might imagine a sort of systematic description - I do not say a science because the term is too galvanized now - that would, in a given society, take as its object the study, analysis, description, and 'reading' (as some like to say nowadays) of these different spaces, of these other places. As a sort of simultaneously mythic and real contestation of the space in which we live, this description could be called heterotopology. ${ }^{3}$

The Hereford map could also be called a heterochronia, a meeting-place for different times. ${ }^{4}$ As for projection, the map is an image of the physical world, with rivers, cities, and coastlines, and its proportions are proportions of importance and

2 Scott D. Westrem, The Hereford World Map: A Transcription and Translation of the Legends with Commentary (London: The Folio Society, 2010), 8.

3 Michel Foucault, "Of Other Spaces: Utopias and Heterotopias," Diacritics 16, no. 1 (Spring, 1986): 24.

4 Foucault, Of Other Spaces, 26. 
meaning - hence the position of Jerusalem, the prominence of biblical history, and the frequency of monsters and horrors on the margins, furthest from the origin of Christianity. In other words, the map is not just a projection of an external, physical world, but of Christian history and thought. While enabling the viewer to explore and remember the Christian world, the map also projects the structure of her own mind: it becomes a site of mystical experience - it is not just a picture of space; the map is space, not a model, but a place, a landscape for meditation and inner pilgrimage, and an icon. The Hereford map is not a representation, but an embodiment of the world. The centre of the world is the centre of Jerusalem, the centre of the map, and the centre of the mind, of attention, of concentration. Finally, like the world, the map is not portable, not to be carried, but to be sought and entered.

The mappa mundi is a cartographic genre which belongs to a specific historical time, the High Middle Ages - although it could be argued that it is still a concept in later, even recent accounts of biblical history. ${ }^{5}$ Still, technical developments in cartography, and, of course, transformations of the concept of the world, made the mappae mundi redundant as a map. The rediscovery of Ptolemaic geography with its use of coordinates gave rise to a cartography which sought to project the physical globe onto a flat sheet while retaining its proportions as faithfully as possible. This basic problem, projecting what is round onto what is flat, does not have any final or perfect solution.

\section{New Maps, Old Meanings}

This chapter is concerned with another problem. In terms of physical precision, the Ptolemaic turn was a huge advancement, but it came at a price: it deprived the world of its centre and hence of its spiritual meaning. North was up, and as the zero meridian came to pass through Greenwich, the common world map became a manifestation of the power of the British empire - but even that was not a manifestation of any deeper meaning or of the multi-layeredness of time. The basic premise of the new geography and the modern maps was that all maps would fit into a geometric system which in itself had no depth. Thus - and this is my question - what happened to meaning, to the world's temporal dimension? More specifically: how could maps adhere to the new, scientific principles of cartography, and still represent the particular quality of Palestine and its surroundings, that it was The Holy Land? The new maps had no hole from the compass - so what would be their point?

5 See Chapter 19 (Erling Sandmo), in volume 3, 390-409. 


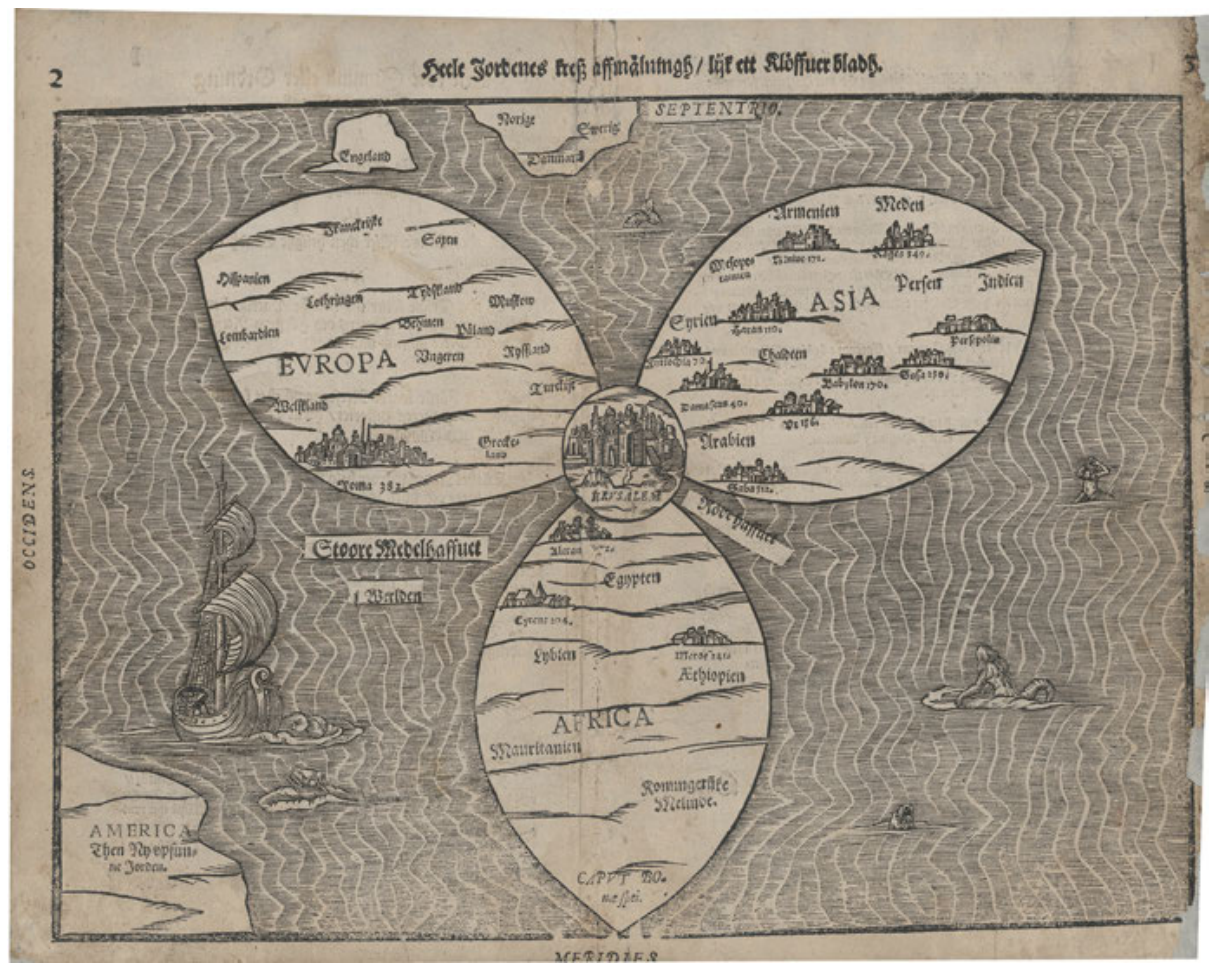

Fig. 10.1: Heinrich Bünting, Heele Jordenes Kretz affmålningh / liik ett Klöffuer bladh ("The Entire Circle of the Earth depicted / like a clover leaf") (1595).

In some instances, the point was obvious enough. One such instance was the biblical text itself, underpinned by a long tradition of Bible commentaries with maps and plans of important events and central locations. Such commentaries had been written and drawn since early Christian times, but the Reformation brought with it a renewed interest in biblical or sacred geography. Maps were present in Protestant Bibles from the beginning, included to support and guide reading. This was also the task of other, non-biblical works, such as the German pastor Heinrich Bünting's Itinerarium Sacræ Scripturæ (1581 and later editions). ${ }^{6}$ Bunting gave his readers - as his title said - an itinerary for the holy scripture, in the form of maps of the world - Europe, Asia, The Holy Land, Jerusalem, and the Temple - as well as a series of descriptions of important travels from the Old and New Testaments. ${ }^{7}$

6 On Bünting’s clover map, see Alfred Hiatt, Terra Incognita: Mapping the Antipodes before 1600 (London: British Library, 2008), $184 \mathrm{ff}$.

7 Heinrich Bünting, Itinerarium sacrae scripturae, das ist, ein Reisebuch über die gantze heilige Schrifft, (Helmstedt, 1581). 
Bünting's work was Lutheran, but it was also an example of a continuity reaching back to the Middle Ages. A striking example of this is another of his maps, a map of the world in the shape of a clover (Fig. 10.1). This map was not Bünting's invention - it was derived from maps going back at least to the first part of the sixteenth century, but still, then, being printed in new editions well into the seventeenth century, also in Scandinavia, both in Swedish and Danish.

The three leaves are the three continents of the Old World Europe, Asia, and Africa, with England placed very close to the European continent. The leaves are joined in Jerusalem. America barely protrudes from the bottom left corner, and Scandinavia from the upper centre. The map's peculiar hybridity lies in the fact that despite its use of the clover both to show how Jerusalem is the centre and arguably - that the history of the Old World grows from this point, it also has traits from Ptolemaic geography: the frame of the map seems to be the borders of the grid of longitudes and latitudes which defined the geography of the inhabitable world. This is the reason only the southern part of Scandinavia is visible: the rest lies beyond the mappable world.

Bünting's 1595 Swedish edition of the clover map (Fig. 10.1) has a special poignancy: it speaks with the language of the marginalized - a language of people not just on, but beyond the frame of Christian world history. And the marginalization was new. It was imposed by the revival of Ptolemaic geography: the mappae mundi maps had only one world and no such borders. This exclusion of parts of Scandinavia - at the time of the clover map, a Lutheran heartland - may appear to be an accidental effect of this spectacular attempt to combine the medieval mapping of time with the Ptolemaic ordering of space. Perhaps there was a kind of compensation in a small detail: the Swedish edition of the clover map added "Norway" to the glimpse of Scandinavia, as if the three Northern countries made up a little peripheral Trinity of their own.

The particular Protestant concern with maps was due both to a need for close reading and explanation of the text and to what was in several cases a ban on images. Maps and diagrams were not depictions in the strict sense, but they still gave the Bibles a visual impact and an explanatory power they would otherwise have lost. ${ }^{8}$ The maps that were eventually printed in Bibles would typically show, first, the Exodus, second, the Land of Canaan (divided amongst the Twelve Tribes of Israel), third, a smaller version of the Holy Land with places mentioned in the Gospels, and finally a map showing places relevant to the Acts of the Apostles. ${ }^{9}$

8 Cf. Elizabeth M. Ingram, “Maps as Readers' Aids: Maps and Plans in Geneva Bibles," Imago Mundi 45 (1993): 29-44; and Justine Walden, “Global Calvinism: The Maps in the Geneva Bible,” in Shaping the World in the Reformation: Books, Scholars and Their Readers in the Sixteenth Century, eds. Bruce Gordon and Matthew McLean, Library of the Written Word 20 (Leiden: Brill, 2012).

9 Catherine Delano Smith, "Maps in Bibles in the Sixteenth Century," The Map Collector 39 (1987): 6. 


\section{Time and Terrain}

The intersection between this renewed sacred or biblical geography and the emerging secular geography brings together two historical fields, each with their own abundant literature. This short chapter can only hint at the vast material and point to the questions raised by the existing research. It relates partly to the new history of cartography, with its emphasis on the cultural production of space and on the role of power, partly to book history, and partly to the more specific field of the history of sacred geography and the importance of maps in Bibles. Interested readers should explore the more general literature in each field.

The first known atlas of Palestine or the Holy Land is the strongly anti-papal Erasmian Catholic Jacob Ziegler's Quae Intus Continentur or Terrae Sanctae, published in Strasbourg in $1532 .{ }^{10}$ By then, maps were already provided by vernacular Bibles. When Christoph Froschauer in Zurich published part of Luther's translation of the Old Testament in 1525, the text was equipped with a double-spread woodcut reproduction of a map drawn by Lucas Cranach. Probably produced at great speed, the map in this first edition was a mirror-image, although most of the names were printed the right way. Subsequent Protestant Bibles featured the Cranach map oriented "correctly", as Catherine Delano-Smith points out - but what was the right way? ${ }^{11}$ Although the first printings of Cranach's map show how this question could be one of attention and technology, it could be said to go straight to the core of early biblical or sacred geography.

Consider, for instance, this map of the Terra Sancta (Fig. 10.2), The Holy Land, from Sebastian Münster's Geographia (1542) as an early example of nonbiblical appropriation of sacred geography. The map shows the territory inhabited by the twelve tribes of Israel, and the final part of the Exodus and the route taken by the Israelites through the desert. On the map, this route begins in the upper left-hand corner. It passes through a series of numbered places, or stations, beginning with 32 and ending on 41. These numbers signify the years of wandering.

What is of particular importance here is that the journey through the stations is mediated as a feature of geography, embedded in the landscape. It could be seen as a narrative, as an itinerary not just for the Israelites, but for the eye and mind of the beholder. However, this is a map from a Cosmographia, a description of the world in terms of geography, ethnography, history, and natural history. It is followed by a map of Taprobane or Sri Lanka, and it is not a devotional map made to accompany

10 The manuscript of the Ziegler Atlas is the property of the Norwegian National Library, Oslo. Cf. Kristian Nissen, "Jacob Ziegler's Palestine Scondia Manuscript University Library, Oslo, Ms. 917-40," Imago Mundi 13 (1956). On Ziegler's biography and theological positions, see Kurt Stadtwald, Roman Popes and German Patriots: Antipapalism in the Politics of the German Humanist Movement from Gregor Heimburg to Martin Luther (Genève: Librairie Drolz, 1996), 105ff.

11 Delano Smith, "Maps in Bibles in the Sixteenth Century," The Map Collector 39 (1987): 4. 


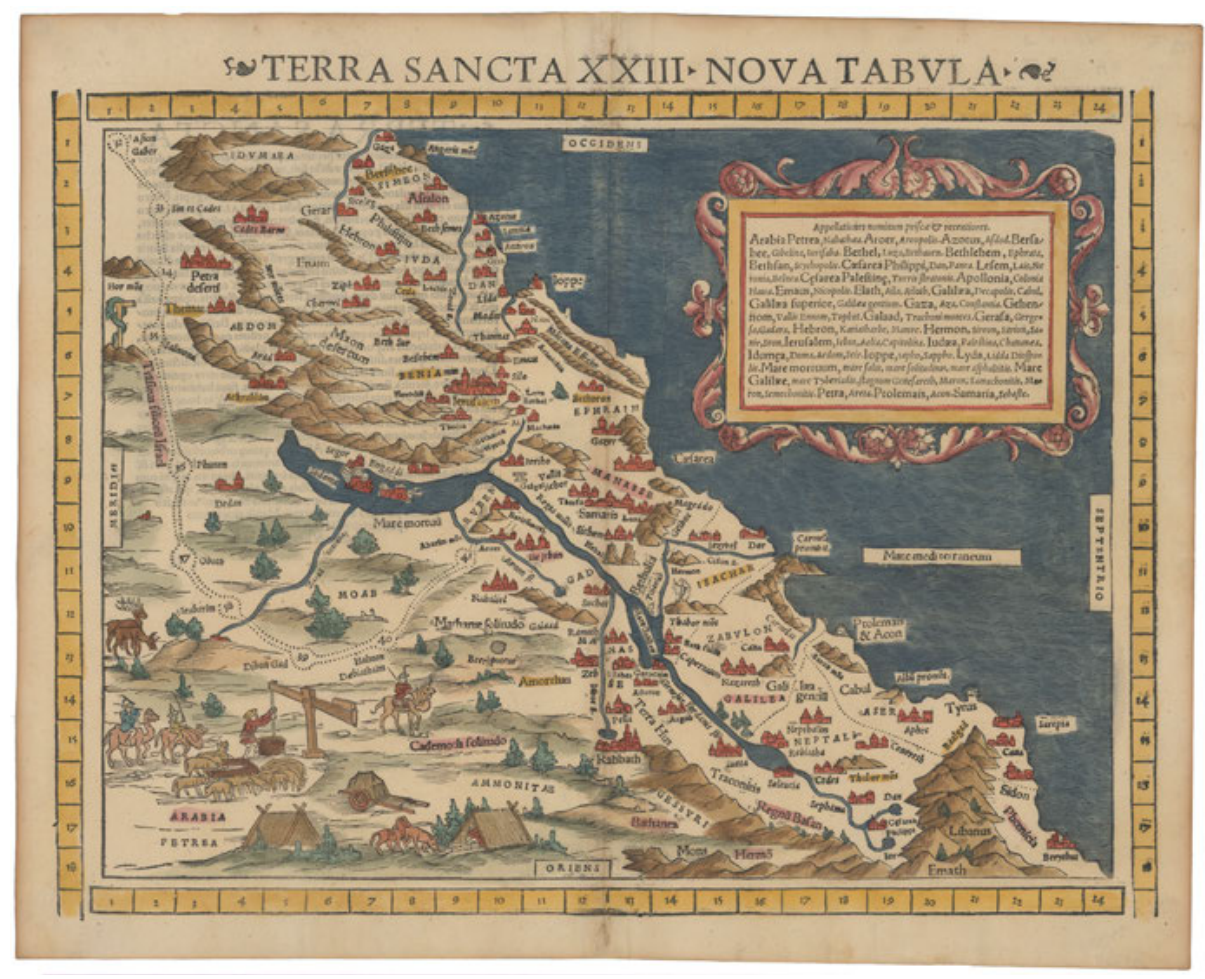

Fig. 10.2: Sebastian Münster, Terra Sancta (1542).

the reading of the Bible. It is a map of a land in the mid-1500s, visualized both by the fact that the first station on the desert route is number 32 and by the scene at the bottom left, where farmers and travelers go about daily lives that appear to be unrelated to biblical history.

Today, the most striking aspect of this map (Fig. 10.2) is - as suggested earlier its geographical orientation. West is up, North to the right. Münster often made choices like this during this point in his career. In Geographia, the orientation of the maps varies and does not appear to follow any kind of systematic pattern. The maps were designed simply to show their objects as clearly as possible. This does not mean that Münster was unaware or disinterested in projection. The map of the Holy Land is preceded by a map of a somewhat larger area of the present Middle East, "according to Ptolemy's description.” It shows Palestine and its surroundings with North up. A brief text in the upper left-hand corner informs the spectator that "Palestine is the Jewish land, sealed off by Jordan from the Orient. A particular map will follow." It is this particular map (Fig. 10.2), then, that followed.

This version of the map of the Holy Land (Fig. 10.2) is of particular interest because of its coordinates. Like the map of the Middle East in Münster's later Cosmographia 


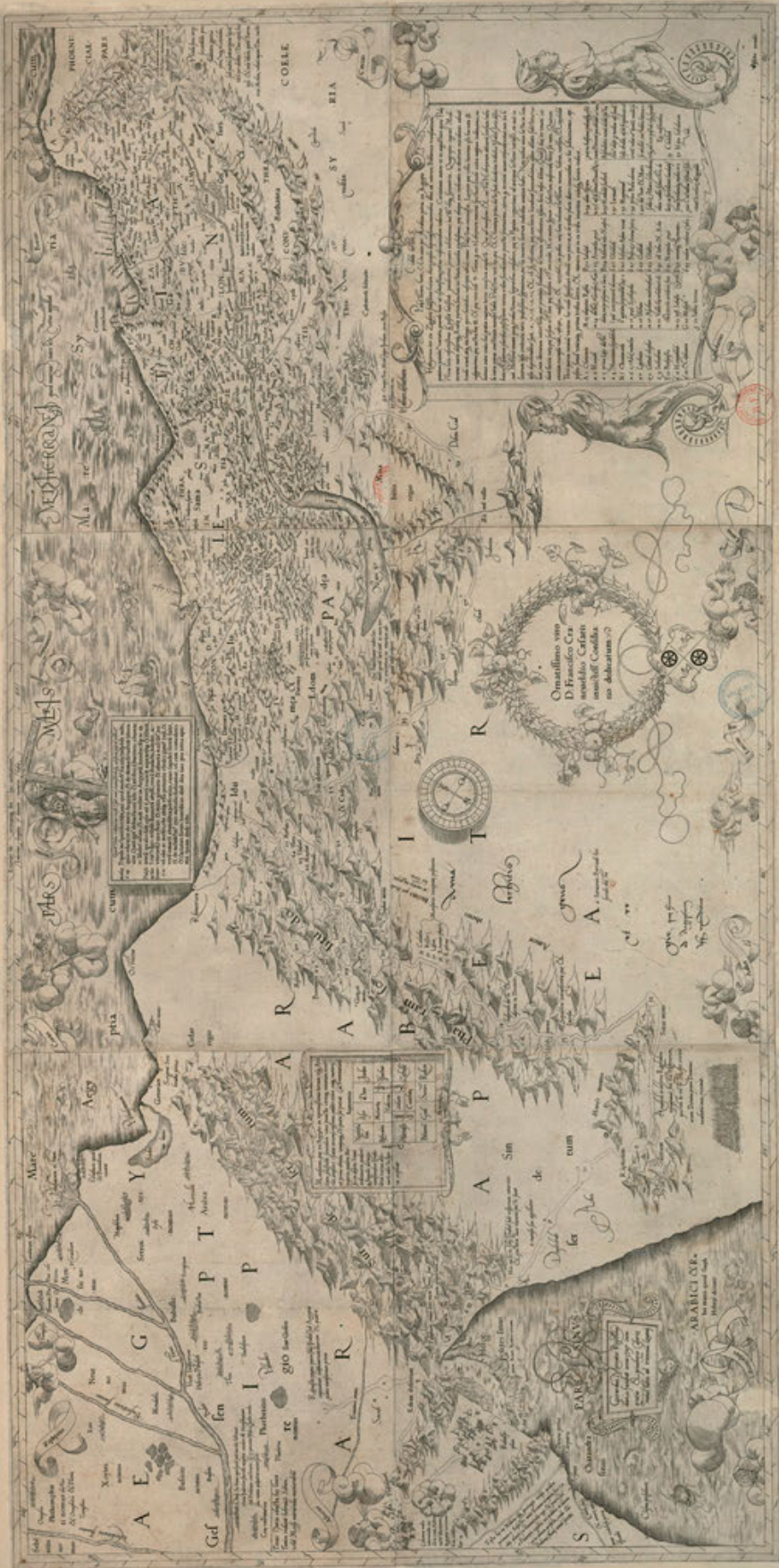


(1544), not depicted in this chapter, it is equipped with coordinates, horizontal and vertical lines with numbers for exact reference. However, the coordinates of the two maps do not match. The coordinates of the 1542 map of the Holy Land begin with 1 in the upper left hand corner and continue to 18 vertically and 24 horizontally. The corresponding coordinates of the Cosmographia map of the Middle East are 39 to 29 and 64 to 81. In other words, the latter is shown to fit the Ptolemaic world map which opens the book. The Holy Land does not belong to the world: the coordinates belong to that particular map only and serves to isolate it from others, not to connect to them.

It seems, then, as if the Holy Land has a separate, sacred geography, even in a non-biblical context - although this geography appears to be very similar to that of other lands. The difference is discreet, apparent in a very particular incompatibility with the new Ptolemaic geography: the coordinates reveal how the map of the Holy Land does not fit into the ordinary, physical world of secular cartography.

Münster's map is a bewildering example of this latter point, since north is to the right rather than up. That may obscure the fact that the Holy Land itself is tilted markedly eastwards, retaining the orientation of medieval cartography. This is a revelation of the persistence of meaning, the bond between the Holy Land, the orient, of dawn, and God.

This double particularity of orientation is a lasting part of Palestine geography. If we turn to the Dutch cartographer Gerard Mercator's map of the Holy Land created in 1537, Amplissima Terrae Sanctae descriptio ad utriusque Testamenti intelligentiam (Fig. 10.3), a description of the Holy Land "for the understanding of both testaments," the map itself is turned slightly to the east, as can be seen from its central compass rose. The coastline of the Holy Land is very close to horizontal, stretching straight east from the Nile delta.

The map of the Terra Sancta is Mercator's earliest known work. He would become the most prominent cartographer of his time, but his development of what is now simply called the Mercator projection belongs to a later stage of his career. His early maps are of particular interest because they reflect his experimental interest in cartographical technique. Projection is of the essence - and so, of course, is geographical orientation.

If we compare Mercator's Terra Sancta map (Fig. 10.3) to the famous double cordiform World Map (Fig. 10.4) made the following year (Fig. 10.4), the most obvious difference is that of projection, but orientations differ as well. In the spectacular heart-shaped map of 1538, the coastline takes a sharp turn northwards west of the Nile.

North in the World Map is located in the upper left corner. The Palestinian coast can be seen to the right of the centre of this detail, oriented north-northeast. It is not marked "Palestine" or "the Holy Land", but "Arabia”.

The projections and general outline of Mercator's maps vary greatly. The heavenly directions remain constant - except in the case of the geography of the Middle East. It changed according to the maps' inherent time - biblical or secular 


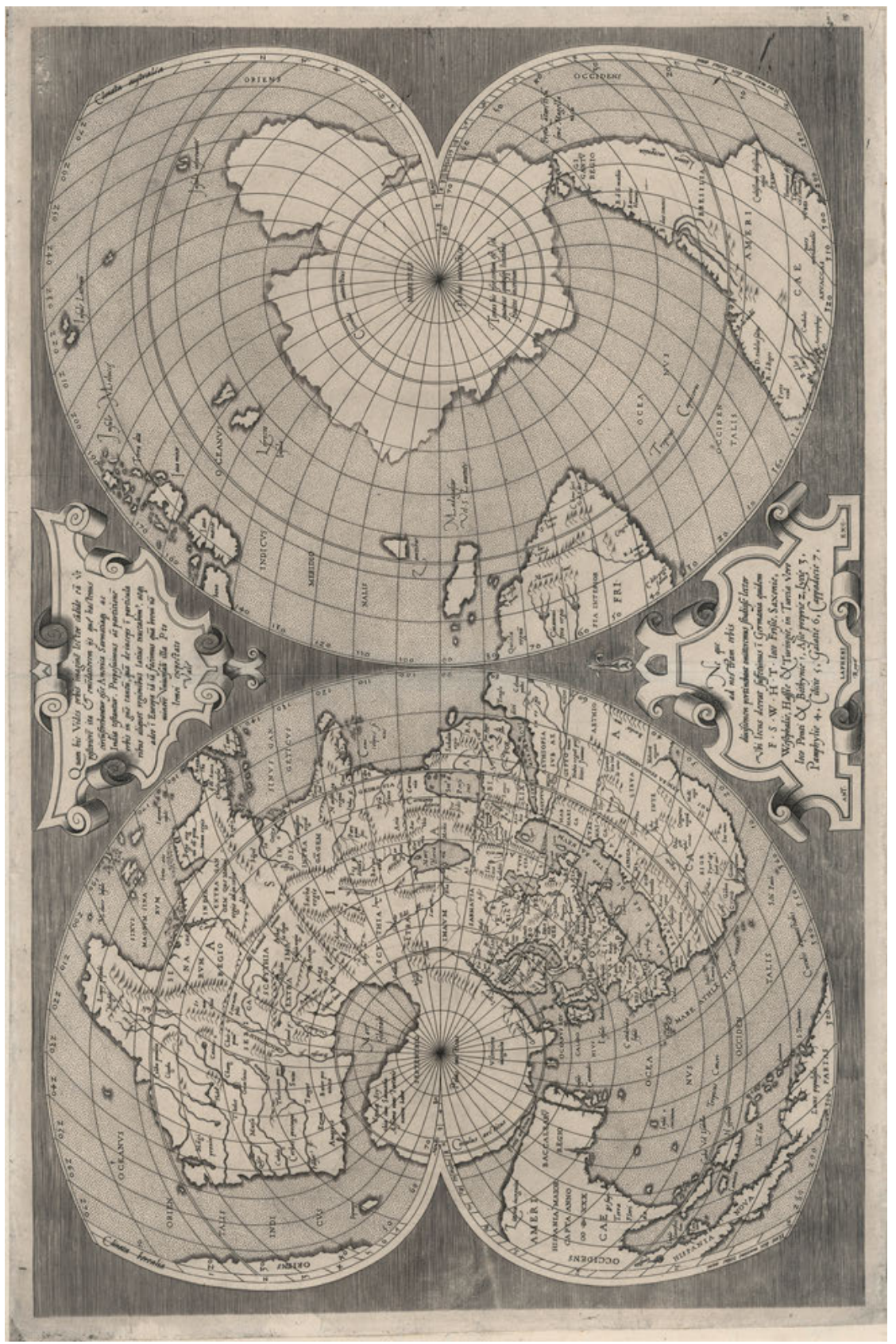

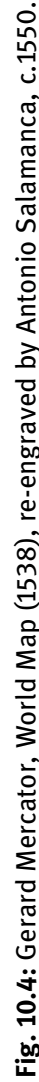


and/or contemporary - and their political territoriality. The coastline of the biblical Holy Land followed the horizontal line from west to east; the coastline of the contemporary Osman Empire between Egypt and Syria ran roughly from south to north. The two regions may appear to occupy the same cartographic space, but this is a superficial identity. Their geographies may be studied through similar maps, but their ontological status is different: one land is sacred and eternal, one worldly and political.

Mercator's Terra Sancta (Fig. 10.3) also features the journey of the Israelites from Egypt to Canaan, the Exodus. A suggestive detail is that the parting of the Red Sea is empty, perhaps "inviting the map's viewer to take the Hebrew's place," to quote Mercator's biographer, Nicholas Crane. ${ }^{12}$ This may be a tall claim, but it makes for interesting comparisons with other maps, and it could be that the void of the open sea was meant to facilitate identification and devotion.

The itinerary is complete, with numbered stations. This makes for an interesting comparison with Münster's map, which begins with station number 32. In Bible maps, the station numbers corresponded with the number of wandering years, but they would also typically refer to a numbered list of passages to be read and contemplated. It is not altogether obvious that the numbers should be included in maps in other settings. The fact that they are suggests that there is no absolute distinction between the sacred and the secular. The Mercator map was a single map and it seems reasonable that it could have had a devotional function; so was Münster's - but that could not possibly have had such a function, since the number of stations was reduced to the final ten. This could be understood as a deliberate suggestion that the landscape depicted was essentially biblical, united with the more purely spatial function of the map, which was to provide information about Palestine. In other words, Münster's map of Palestine was also an image of another map of the Holy Land. Behind the immediate depiction of Palestine lay another, only partially visible, of the Exodus.

Even more striking in this respect is the depiction of the life and travels of Abraham in the Flemish cartographer Abraham Ortelius's Theatri Orbis Terrarum Parergon; Sive Veteris Geographiae Tabulae, Commentarijs Geographicis et Historicis illustratae (Fig. 10.5), a 1586 supplement to his earlier Theatrum Orbis Terrarum (1570). The Parergon is primarily a historical atlas. It contains redrawings of old and antique maps, contrasting examples of older and contemporary cartography, and a series of maps with biblical topics. One of these is devoted to Abraham. We see twenty-two miniature images of scenes from Abraham's life surrounding a map of Canaan - that is, they do not surround a map, but an image of a map, depicted as if hanging from two nails driven into the wall of the page.

12 Nicholas Crane, Mercator: The Man Who Mapped the Planet (London: Weidenfeld \& Nicolson, 2002), 88. 


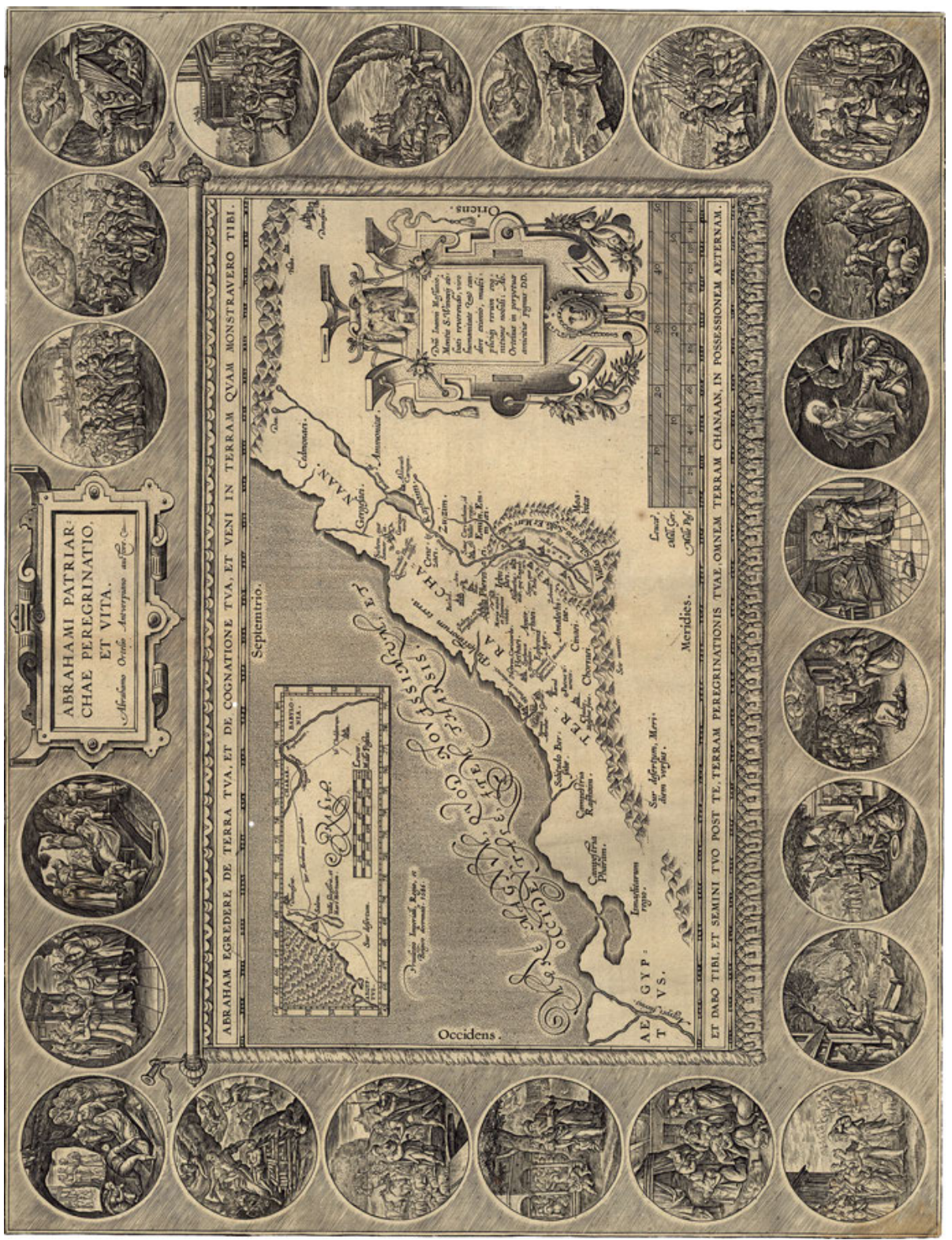


It is as if Ortelius pre-echoes his much later countryman, the Belgian painter René Magritte: this is not a map, but a picture of a map. ${ }^{13}$ It is a trompe l'oeil image, depicted in a way which highlights the map as an object and not just as a representation of its landscape. I would argue that in this case, the representation of the map serves to emphasize how a map of the Holy Land is a map of a particular kind, an object of religious contemplation, even of worship. ${ }^{14}$ Although different from the Hereford mappa mundi in all technical respects, the Abraham map-image seems to suggest a continuity in the perception of the map as a physical and even sacred place in itself. The mappa mundi's central hole is gone, but the implied holes from the illusory nails seem to retain some of its religious significance.

The peculiar ontological status of the map, which is both a representation of a landscape and an object of devotion, is made even more complex by the care for scale and measurements. The main map shows Canaan; the smaller, inserted map shows the travels of Abraham from Ur in Chaldea to Canaan, Egypt, and Hebron. This map has coordinates which match those of contemporary, secular cartography. The larger map has no coordinates, but both present scale according to two different Roman measures of distance, leucæ and mille passus, both Roman units. Mille passus may then have been the unit used by the Romans in Palestine, the depicted land, whereas leucæ was used in Gaul - that is, in northwestern Europe, the location of the implied reader.

There is no paradox in this concern with both faith and exactitude. Rather the opposite - this is an example of what Zur Shalev has called "devout curiosity":

Measurement and accuracy were happily adopted as pious modes of dealing with the sacred, in text and image, because they were not seen by contemporaries as emptying the world of its moral and qualitative properties. Curiosity becomes a devout act in itself . . . Devout curiosity meant not only the careful study of biblical and ecclesiastical antiquity, but also mobilizing this study for contemporary devout purposes. ${ }^{15}$

\section{The Paradoxes of Orientation}

The Hereford mappa mundi was a holistic map, an image of a world consisting of different times as well as different spaces. The new Ptolemaic geography rendered

\footnotetext{
13 Michel Foucault, This is a Not a Pipe, ed. and trans. by James Harkness. (Berkley, CA: University of California Press, 1982).

14 On the persistence of religious thought in sacred cartography, exemplified by Ortelius's Parergon, see Walter S. Melion, "Ad ductum itineris et dispositionem mansionum Ostendendam: Meditation, Vocation, and Sacred History in Abraham Ortelius's Parergon," The Journal of the Walters Art Gallery 57 (Place and Culture in Northern Art) (1999).

15 Zur Shalev, Sacred Words and Worlds: Geography, Religion, and Scholarship, 1550-1700, History of Science and Medicine Library 21 (Leiden: Brill, 2012), 13.
} 
such maps obsolete. Cartography eventually came to be the visual representation of pure, physical space - even when the space served as the foundation for thematic maps. Conversely, historiography developed into the textual representation of time as the ordering of past events. The cartography of Palestine or the Holy Land shows how slow and nuanced this transition was. Biblical geography produced some of the largest and most detailed maps of the Holy Land, such as those in Gustav Adolf's Swedish Bible from 1618, Elzevier's Dutch States Bible from 1663, and Charles XII's Swedish Bible from 1703. ${ }^{16}$ Maps that were not embedded in Bibles also maintained many of the hallmarks of sacred geography and singled out the Holy Land as geographically unique.

One such hallmark was the geographical direction of the coastline of the Holy Land. When mapped as part of a larger region, the world or the Mediterranean, the coastline would typically be pictured as following an almost vertical north/south line. In the maps devoted specifically to the Holy Land the coast would, as mentioned earlier, lean eastwards. Ortelius' image of Abraham's pilgrimages (Fig. 10.5) may already be a subtle example: The larger of the two maps in this image leans noticeably more to the east than the smaller, and the explanation could be that the smaller map shows a land which has not yet become part of sacred history and consequently is not yet leaning toward the east.

The unpredictability and particularity of orientation remained a general aspect of the early modern cartography of the Holy Land - but only so long as it was represented as sacred. In the 1632 edition of Mercator's great atlas, Atlas sive Cosmographicae meditationes de fabrica mundi et fabricati figura , the contrast between past and present is very sharp. ${ }^{17}$ As part of the Ottoman Empire "Turcicum Imperium" - Palestine stretches north/; as the Holy Land, it is depicted with east at the top (Fig. 10.7).

The contrast between the two geographies appears to be both pronounced and fading. The eastern orientation of the second map is dramatic, but the geography matches what was by then common knowledge in secular cartography. This is further emphasized by the coordinates, which show that the Holy Land in every geographical sense is identical to Palestine, part of the Ottoman Empire. ${ }^{18}$

This particular atlas cannot be taken as proof of a linear development, of a convergence of the geographies of Palestine and the Holy Land. Many of the maps in question were almost certainly based on older models. Only four years later, the

16 Biblia, thet är all then heliga skrift på swensko (Stockholm: Henrich Keysers Tryckeri, 1703). Biblia thet är all then helga scrifft, på swensko (Stockholm: Oloff Oloffson, 1618); Johan Elzevier, Biblia, dat is, se gantsche heylige schrifture (Amsterdam: Johan Elzevier, 1663).

17 Jodocus Hondius and Gerard Mercator, Atlas sive Cosmographicae Meditationes (Amsterdam: Cloppenburg, 1632).

18 This can not be seen as the evidence of a linear development. The map of the Holy Land in the 1636 English edition of Mercator - Hondius - Janssonius Atlas has no coordinates. 


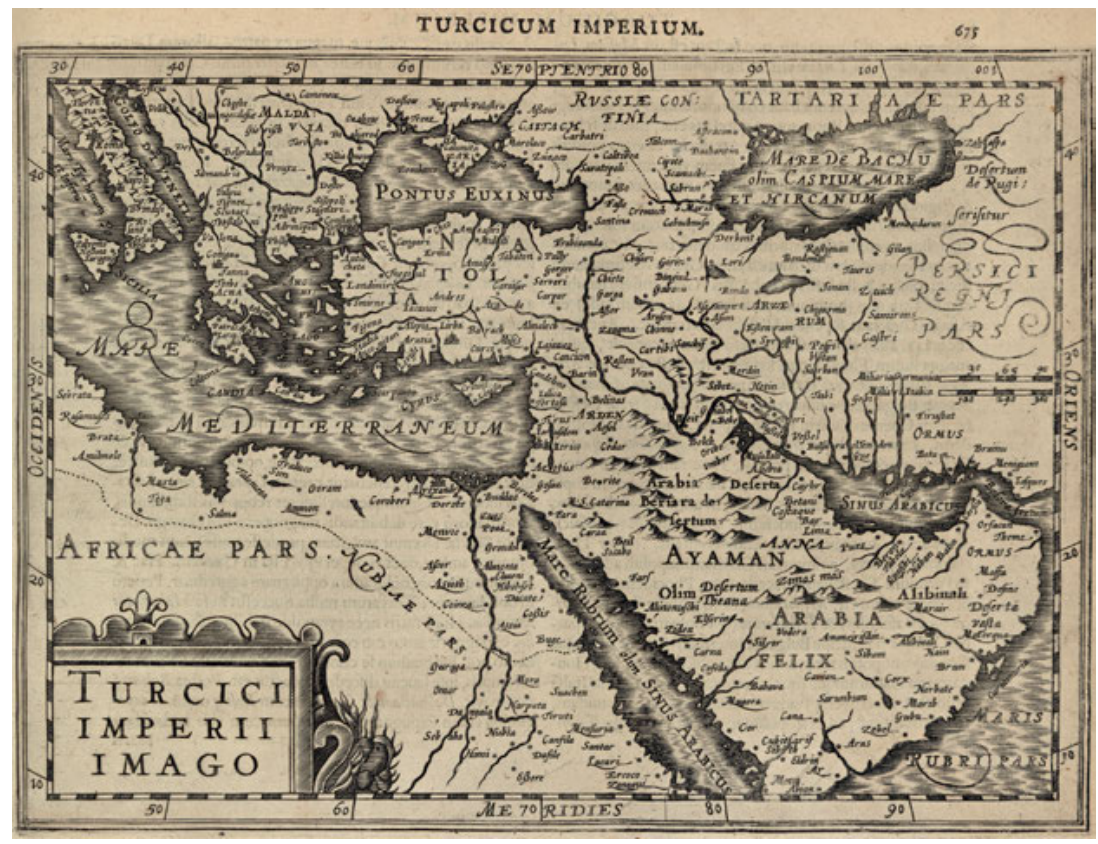

Fig. 10.6: Turcicum Imperium, Mercator/Hondius (1632).

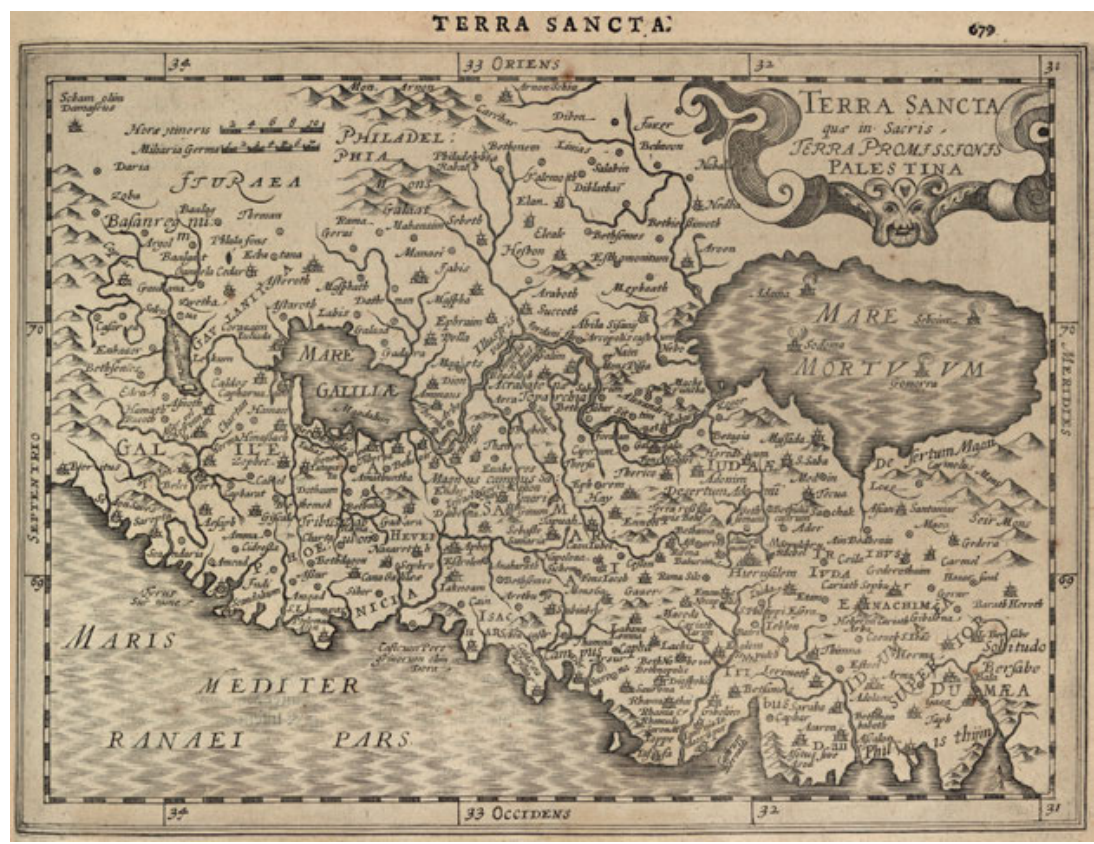

Fig. 10.7: Terra Sancta, Mercator/Hondius (1632). 


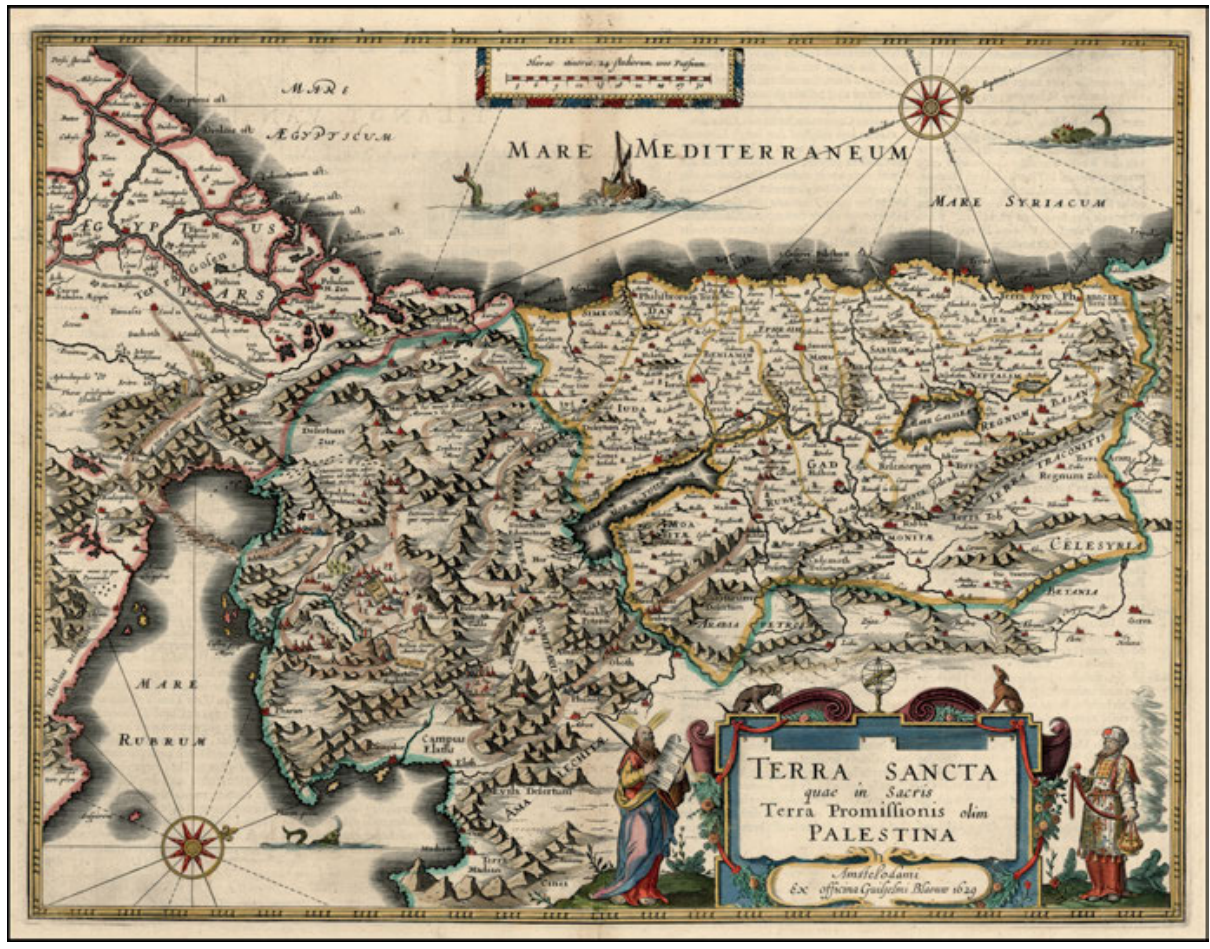

Fig. 10.8: Joannes Blaeu, Terra Sancta, from Atlas Maior (Amsterdam: Blaeu, 1662).

Flemish cartographer Jodocus Hondius and his Dutch colleague Joannes Janssonius published another edition of the Mercator Atlas where the map of the Holy Land does not have coordinates (not depicted in this chapter). In Hondius and Janssonius' Mercator Atlas, the coastline, although shown as horizontal, slants towards the east: were it not for the wealth of detail, this map could have been made almost a century earlier. Still, it seems that a form of synchronization of geographies is taking place, and in the 1632 atlas (Fig. 10.6), they are the same - the maps are simply two views of the same object, physically speaking. The Terra Sancta does not feature the Israelites' journey.

In this respect, the Terra Sancta map in the Dutch publisher and cartographer Joannes Blaeu's monumental Atlas Maior (Fig. 10.8) is a nod to the previous century, with its horizontal coastline, its eastern slant, and its absence of coordinates. It also features the journey, prominently displayed, even equipped with a small number of references to biblical verses. The Red Sea seems to be pictured as it swallows the Egyptian army, spears and men disappearing in the waves - eye-catching historical drama, but not an invitation for the reader to be drawn into the Exodus, if we are to follow Nicholas Crane's observation of the openness of this scene in 
Mercator's map mentioned above. ${ }^{19}$ However, the itinerary does not have numbered stations and does not seem to be an aid for reading the text. It is a map which fights a lost cause, that of a particular sacred geography.

Half a century after Blaeu, German cartographer and publisher Johann Baptist Homann included a map of the Holy Land in his Atlas über die Gantze Welt (1714). ${ }^{20}$ Its most spectacular feature is the lower right corner, where two figures - probably Moses and Aaron - are unfolding another map, which shows the journey of the Israelites. Their track has numbered stations, as in the maps of the old biblical geography, and Homann shows the itinerary crossing the Red Sea. However, this pictured map is clearly another object, distinct from the main map of the Atlas proper. It is pondered by the biblical figures themselves, and lost to the implied viewer, recalling rather than recreating tradition.

\section{Conclusion: The Invention of Secular Space}

My main concern here has been to outline a slow change in the relationship between biblical and what may be called a secular geography in the sixteenth and seventeenth centuries. Biblical geography had deep historical roots; secular geography was in a period of rapid change, following the renaissance of Ptolemaic geography and a series of discoveries so great that they contributed to a transformation of cartography itself. This transformation may appear to have entailed a loss of meaning, of depth - an early Entzauberung der Welt, to quote Max Weber. My examples, on the other hand, suggest that meaning and faith seem to have been maintained in oblique, even surprising ways, also in maps that adhered to the emerging secular geography at a time when the northwards orientation was becoming a standard. Even if the atlases that in several of my examples surrounded these maps of the Terra Sancta were oriented in this way, these particular maps were not.

Gradually, the secular inclusion of biblical geography gave way to what - again, simplistically - was a secularization of geography and cartography as a whole. This development could be called the invention of secular cartography rather than its secularization. It was a rupture which, like the Reformation, was both a farewell and a beginning.

The change was gradual, and was not linear. Given the rapid spread of maps and ideas, it may seem surprising that such a marked development was constantly being subverted and set aside - as when the highly secularized Atlas by Mercator in 1632 (Fig. 10.6) was followed only a few years later by a version which was much

19 Crane, Mercator, 2002.

20 Johann Baptist Homann, Atlas über die gantze Welt (Nuremberg: Johann Ernst Adelbulner, 1714). 
more traditional and biblical in its approach to the Holy Land. The explanation must be found both in the localized nature of the production of maps and in the transnational networks of the cartography business. Different cartographers catered to a multitude of audiences, providing exactitude and mysticism alike. Some readers would desire to follow the Israelites from Egypt to the Holy Land and to behold a foreign geography; others merely wanted to study the different parts of the present Ottoman Empire. Many would have wanted the best of two worlds. By the eighteenth century, those two worlds had separated - but neither had been lost. 